Emir. J. Food Agric. 2007. 19 (2): 38-47

http://www.cfa.uaeu.ac.ae/research/ejfa.htm

\title{
Effect of micro-finance on small scale poultry business in South Western Nigeria
}

\author{
K. A. Akanni \\ Department of Agricultural Economics, Olabisi Onabanjo University, \\ P.M.B.2002, Ago-Iwoye, Ogun State, Nigeria
}

\begin{abstract}
In the South Western region of Nigeria many small scale poultry farmers complain of limited access to funds. This is often linked with their low level of farm income and insufficient collateral securities. There is therefore low productivity in the sub sector. The resultant effect of this is the attendant decline in the quality and quantity of the poultry produce people now consume. These operators were selected through multi stage sampling technique. Both descriptive statistics and the Tobit regression model were used for the analysis of data. Only $76 \%$ of the farmers were up to 60 years of age while $69.64 \%$ had up to secondary school education. Average period of poultry experience was 8.06 years while the average farm household size was 12 members. $61 \%$ of these farmers sourced their funds from personal savings while $20 \%$ used loans from co-operative societies. The sigma square $\left(\sigma^{2}\right)$ value of 0.5448 indicated a good fit for the model and a normal distribution of the error term. Level of education, years of experience in poultry keeping and number of poultry birds were positively significant variables. Intensity of funding was highest for input usage $(0.1318)$ and least for experience (0.0013).As a policy measure, issues relating to education, years of experience, lending rates and size of poultry farms needed some attention. This was necessary to ensure a higher fund security index (FSI) for small-scale industry.
\end{abstract}

Keywords: Poultry industry; fund security index; South Western Nigeria
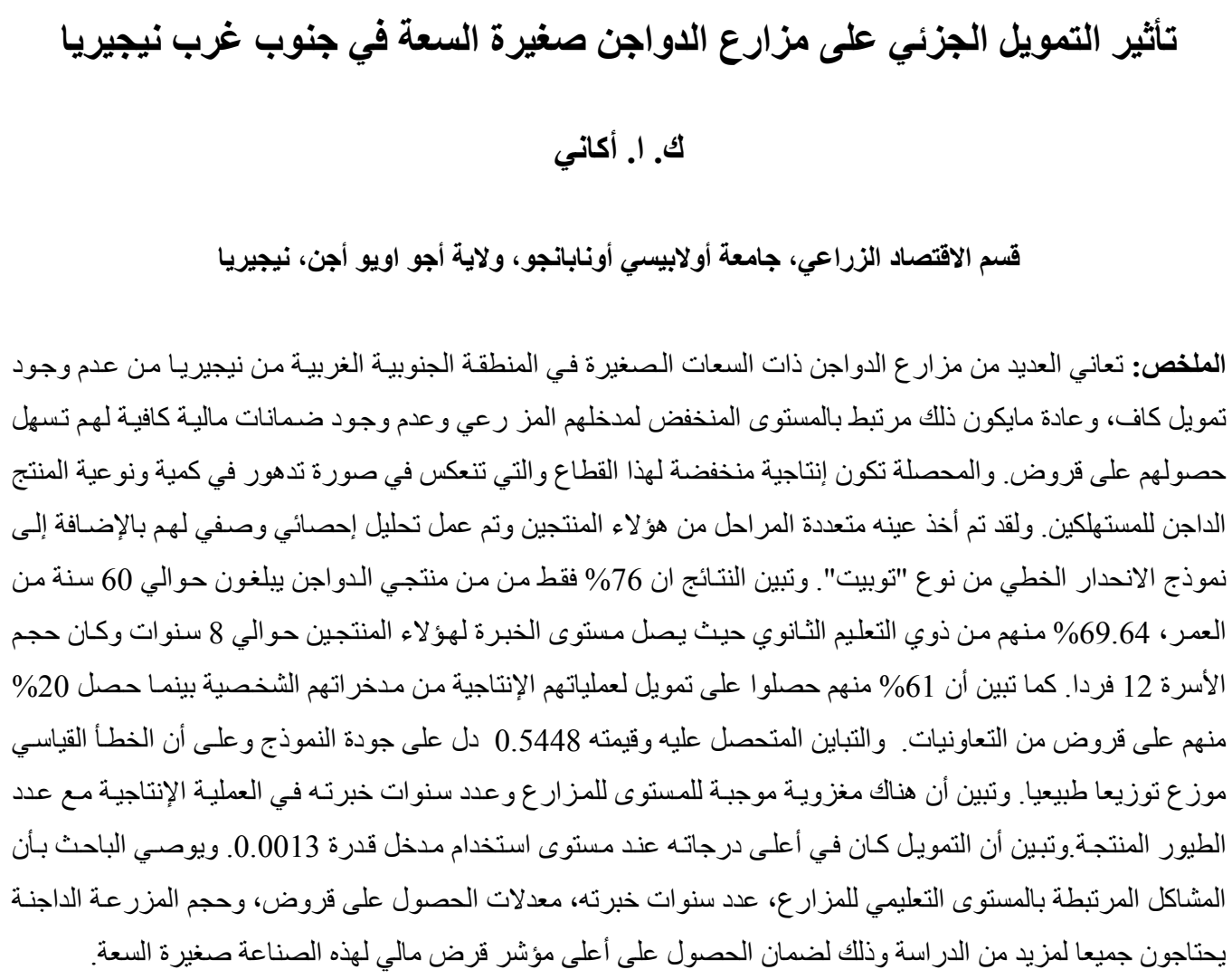


\section{Introduction}

The poultry industry plays important roles in the development of Nigerian economy. It is a major source of eggs and meat which have a high nutritional value particularly in the supply of protein. Eggs are also important in the preparation of confectionary and vaccines. The poultry industry also provides employment opportunities for the populace, thereby serving as a source of income to the people. However, the poultry industry in Nigeria, as well as other developing countries of Africa, is continually characterized by low production levels (Okoli, 1991).This is largely associated with lack or limited finance (credit facilities) for the procurement of basic poultry equipment and materials. Feed ingredients are also expensive. This makes it difficult for the farmers to produce and supply sufficient and good quality feeds to the poultry birds (Oyenuga et al., 1977; Ogunfowora et al., 1975).

Oboth (2003) observed that about 88.9 percent of the poultry farms were funded to the tune of N2.5 million per annum while the average annual funding rate was N1.701 million (Table 1). This thus indicated the poor funding status of the small scale poultry farms in South Western Nigeria. It was also reported that only $4.21 \%$ of the poultry farms had between N3.1 -N3.5 million funding rate per year. As the majority of these farms operated below fund secure level, there were limited credit facilities to procure necessary items such as high quality and abundant feeds, drugs and vaccines, cages and feeding troughs, hybrid chicks and so on. Funds were also required for settling workers' salaries, constructing feed mills and rendering various marketing services. The low level of credit supply to the poultry farms therefore limits productivity and expansion in the sub-sector. To enhance performance in the small scale commercial poultry farms, therefore, adequate and timely release of funds that will see the farms beyond the fund insecure zone is essential. This could be made possible through joint efforts of the private investors, government agencies and co-operative societies.

Table 1. Annual Funding rate of poultry farms.

\begin{tabular}{lccc}
\hline $\begin{array}{l}\text { Funding/Year } \\
\text { (N'million) }\end{array}$ & Frequency & $\begin{array}{c}\text { Percentage of } \\
\text { total }\end{array}$ & Cumulative \% \\
\hline$<1.0$ & 45 & 21.02 & 21.02 \\
$1.0 \leq 1.5$ & 51 & 23.83 & 44.85 \\
$1.6 \leq 2.0$ & 48 & 22.43 & 67.28 \\
$2.1 \leq 2.5$ & 46 & 21.50 & 88.78 \\
$2.6 \leq 3.0$ & 15 & 7.01 & 95.79 \\
$3.1 \leq 3.5$ & 09 & 4.21 & 100.0 \\
TOTAL & 214 & 100.0 & \\
\hline
\end{tabular}

Average annual funding rate $=\mathrm{N} 1.701$ million

Source: Oboth, 2003

Succinctly put, micro-finance consists of money (credit facilities) made available to entrepreneurs for executing certain developmental projects. In poultry production, these facilities could be referred to as the money used to procure poultry materials such as feeds, cages, construction of feed mills and pens, payment of workers' salaries and so on.
It has been argued that if only sufficient agricultural finance was made available, the decline in the production and supply of poultry products in Nigeria, would improve (Oludimu and Fabiyi, 1983). An increase in the level of finance of the poultry industry, better management practices, leading to good nutritional egg and meat production, are 
required to supply the essential protein for the population (Oboth, 2003). Again, poultry production is considered a high risk investment by most financial institutions due to high rate of poultry mortality, low productivity in many cases and low levels of loan repayments. This situation has led to skepticism on the part of financiers when considering financial requests for poultry production. At present a large proportion of the operators in small scale poultry industry in South Western Nigeria are in poverty due to poor financial standing and high business risk which reduces the level of accruable profit (Oludimu, Awojobi and Akanni, 2004). There is thus a growing concern for lack of credit to the poultry farmers even though there are credit policies on the ground. For instance, in the year 2000 , a total of N5 million was provided by the federal government through the Nigerian Agricultural Cooperative and Rural Development Bank as an investment revolving fund in each local government area in the country, (FRN, 2000).

The objective of this study therefore was to examine the extent of micro financing in small scale poultry and the implications for poultry industry in South Western Nigeria. The result of the research will guide policy makers and bankers in designing and implementing appropriate strategies required to improve the level of micro financing in the poultry industry.

\section{Literature Review}

In this section, the review of the literature on micro finance was discussed. This is because of its relevance to smallscale poultry business in Nigeria and in most developing countries of Africa.

In an attempt to justify the importance of farm credits, Ahrendsen et al. (2005) noted that the Federal farm credit programmes currently administered by the United State Department of Agriculture [USDA] were initiated to help the farm sector cope with natural disasters. In a similar vein, Ellinger et al. (2005) observed that the performance, management and risk exposure of financial institutions operating in rural and agricultural markets determine the cost of agriculture's access to financial capital.

Kota (2007), in 'Microfinance: Banking for the poor', with special reference to women in the rural Bangladesh, also noted that borrowing on terms was difficult and sometimes unaffordable. It was observed that the borrowing terms of $2 \%$ of the loan per week which were dictated by the microfinance institutions (MFIs) were much lower than the $150 \%$ interest rate that local money lenders demanded. Many enthusiasts therefore believed that microfinance was an important tool in the effort to end world poverty. Whether they are right is still open to question. Kota (2007) again observed that microfinance customers lived in both rural and urban areas. The rural poor borrow for cattle fattening, dairy farming, poultry farming, bamboo making or weaving. The urban poor, however, borrow to become street vendors, rickshaw drivers, carpenters and artisans. Moreover, microfinance has moved well beyond its roots in Nigeria. As some microfinance institutions now serve poor people in industrial countries.

In a report by 'The Micro Credit Summit Campaign' 64 million people benefited from microfinance worldwide in 2006 as against 9.27 million people in 2000 (Table 2). The number of verified microfinance institutions had also increased from 98 to 420 between the same periods. 


\section{K. A. Akanni}

Table 2. Increasing trends in global beneficiaries of microfinance [2000-2006].

\begin{tabular}{ccc}
\hline Year & No of verified Institutions & $\begin{array}{c}\text { Number of verified poorest } \\
\text { clients }\end{array}$ \\
\hline 2000 & 78 & $9,274,385$ \\
2001 & 138 & $12,752,645$ \\
2002 & 211 & $21,771,448$ \\
2003 & 234 & $35,837,356$ \\
2004 & 286 & $47,458,191$ \\
2005 & 330 & $58,450,926$ \\
2006 & 420 & $64,062,221$ \\
\hline
\end{tabular}

Source:State of the Micro Credit Summit Campaign Report [2006]

Interest rates on micro loans ranged from $20 \%$ to $35 \%$ (even after adjusting for inflation). MFIs are subject to significantly higher costs than commercial banks, because of lending and administrative costs. It is however generally believed that despite the high interest rates, microfinance loans provided positive welfare benefits for borrowers and the costs of doing business will fall as the infrastructure of the industry grew.

\section{Materials and Method}

The study area covered the five (5) states in South Western Nigeria: Ogun, Oyo, Osun, Ekiti and Ondo States. The poultry business is very popular among the residents of the area as there is a ready market for the poultry products.

Primary data which were collected with the aid of sets of structured questionnaires were sourced from small scale commercial poultry farms scattered over the states. A multi-stage sampling technique was used in obtaining the data from the field. The respondents were the operators of commercial (small-scale) poultry farms having less than 3000 birds per farm. Forty five (45) poultry farms were sampled from each of the five (5) South Western States. Thus, 225 poultry farms were sampled for the study. The sets of questionnaire were personally administered to the operators of poultry farms between February and October, 2006.

Information was sought on the socioeconomic characteristics of the poultry farmers, their sources and level of access to micro-finance etc. Descriptive statistics and Tobit model were used in the analysis of data. The descriptive statistical method was used to explain the socio- economic characteristics of the poultry farmers. This involved the use of frequency tables and percentages.

The Tobit regression model was used to identify the determinants of the use of micro finance by poultry operators. It measures the parameters of the conditional probability of having access to required funds and the effects of the marginal changes in explaining variables on the micro finance status of the poultry farms. Following from McDonald and Moffit (1980) as adapted by Adesina and Baidu-Forson, [1995], and Baidu-Forson, (1999), the model is expressed as;

$\mathrm{MF}_{\mathrm{i}}=\beta_{\mathrm{i}} \mathrm{Xi}+\varepsilon_{\mathrm{i}}-\mathrm{C}(1)$, where

$\mathrm{MF}_{\mathrm{i}}=$ Probability of adequate microfinancing or volume of financing, for $G_{i}$ $\geq \mathrm{Z}$.

$\mathrm{MF}_{\mathrm{i}}=$ is continuous if $\mathrm{MF}_{\mathrm{i}} \geq \mathrm{MFo}$

$\mathrm{MFi}=0$ if $\mathrm{MF}_{\mathrm{i}} \leq \mathrm{MF}_{\mathrm{o}}$ 
$\mathrm{MF}_{\mathrm{o}}=$ the non- observable threshold level.

$\mathrm{X}_{\mathrm{i}}=$ Vector of explanatory variables

$\beta_{\mathrm{i}}=$ Vector of respective parameters

$\varepsilon_{\mathrm{i}}=$ Independently distributed error term

$\mathrm{MF}=\quad$ Volume of financing/funding (Naira,N*)

$\mathrm{Z}=$ Fund Insecurity line

$\mathrm{G}_{\mathrm{i}}=$ Intensity of Micro-financing which is defined as:

$\left(\mathrm{W}_{\mathrm{i}}-\mathrm{Y}_{\mathrm{i}}\right) / \mathrm{W}_{\mathrm{i}}$ and,

$\mathrm{W}_{\mathrm{i}}=$ Optimum funding level (Naira, $\mathrm{N}^{*}$ )

$\mathrm{Y}_{\mathrm{i}}=$ Mean Poultry farm per capita expenditure $(\mathrm{N})$

The explanatory variables which describe the effect of the use of micro finance on the output of poultry farms are:

$\mathrm{X}_{1}=$ Age $(\mathrm{yrs})$

$\mathrm{X}_{2}=$ Educational Status (yrs)

$\mathrm{X}_{3}=\quad$ Poultry Keeping Experience (Years)

$\mathrm{X}_{4}=$ household Size (No)

$\mathrm{X}_{5}=$ Interest rate $(\%)$

$\mathrm{X}_{6}=$ Number of Birds (No)

$\mathrm{X}_{7}=$ Total Annual Expenditure (Naira, $\left.\mathrm{N}^{*}\right)$
$\mathrm{X}_{8}=$ Gender of Poultry farm operator $(1,0)$

$\mathrm{X}_{9}=$ Value of Inputs e.g. feeds, drugs, water etc (Naira, $\mathrm{N}^{*}$ )

Note: Naira, $\mathbf{N}^{*}=$ the Nigerian currency unit

Eleven (11) of the 225 poultry farms sampled for the study were not analyzed due to incomplete information and/or non response. Therefore only 214 samples were properly analyzed.

\section{Results and Discussion}

Before making any estimation of the empirical model some socio-economic characteristics of the operators of the poultry farms are explained. Issues of sources of finance, the age distribution, educational status, poultry keeping experience, and household size of the poultry farm operators are statistically analyzed and discussed here.

\section{A. Age distribution of the poultry farmers}

Results indicated that $76 \%$ of the farmers were below 60 years of age (Table 3) while the average age was 46.54 years. This thus implying that these farmers were within the active working age bracket. Again $41 \%$ of these farmers were 40 years old and below. These are particularly young people who could afford to venture into the poultry business which is known to be characterized by risks such as disease, fire outbreak and burglary.

Table 3. Age distribution of the poultry farmers.

\begin{tabular}{lccc}
\hline Class Interval & Frequency & Percentage $\%$ & Cumulative \% \\
\hline $21 \leq 40$ & 88 & 41.12 & 41.12 \\
$41 \leq 60$ & 75 & 35.05 & 76.17 \\
$>60$ & 51 & 23.83 & 100.00 \\
Total & 214 & 100 & \\
\hline
\end{tabular}

Average age $=46.54$ years

Source: Field survey, 2006 


\section{B. Educational status of poultry farmers}

About 9.0 percent of the poultry farmers had no formal education while 69.64 percent had up to secondary school education (Table 4). On the whole, poultry farmers need to have good education on poultry keeping so that they are able to properly harness all available resources to the advantage of production process. With this, the level of production per poultry farm will increase. Knowledge about the latest research efforts in the areas of genetic engineering and health management particularly as they affect the prevention of communicable diseases such as avian influenza is necessary for effective performance and increased productivity of the poultry industry.

Table 4. Educational status of the respondents.

\begin{tabular}{lccc}
\hline Level of Education & Frequency & Percentage \% & Cumulative Percentage \\
\hline No formal Education & 19 & 8.90 & 8.90 \\
Primary Education & 36 & 16.82 & 25.72 \\
Secondary Education & 94 & 43.94 & 69.66 \\
Tertiary Education & 65 & 30.36 & 100.0 \\
Total & 214 & 100.0 & \\
\hline
\end{tabular}

Source: Field survey, 2006

\section{Farming experience of poultry farmers}

About 70.0 percent of the poultry farm operators had up to 10 -year poultry keeping experience while the average period of poultry keeping experience was 8.06 years (Table 5). Expectedly, the more the number of years of experience in poultry keeping, the better the ability to manage the poultry business well. Cases of disease attack, fire outbreaks, poor feed quality and pilferage should be better handled by experienced poultry farmers. With better handling of production resources in poultry, there should be a higher level of production in the industry. This will ultimately translate to increased income level for the poultry farmers.

Table 5. Farming experience of the respondents.

\begin{tabular}{lccc}
\hline Experience & Frequency & Percentage \% & Cumulative Percentage \\
\hline$<5$ & 64 & 29.90 & 29.90 \\
$5 \leq 10$ & 85 & 39.72 & 69.62 \\
$11 \leq 15$ & 42 & 19.63 & 89.25 \\
$>15$ & 23 & 10.75 & 100.0 \\
Total & 214 & 100.0 & \\
\hline
\end{tabular}

Average period of poultry keeping experience $=8.06$ years

Source: Field Data,2006

\section{Household size of poultry farmers}

Thirty-eight (38) percent of the poultry farmers had up to 10 household members while 34.11 percent (or 73 poultry farmers) had a household size of between
11 and 15 members (Table 6). The average household member was however 12.07. This implies that the poultry farm operators in South Western Nigeria generally had a large family size. The 
family might be exploited as cheap sources of labour for the poultry farms. However, large family sizes might be a drain for business profit, as household expenditure, particularly on consumption, is high. This basically explains why most small scale farms close down when they could no longer provide the required funds for their smooth operation.

Table 6. Household size of the respondents.

\begin{tabular}{lccc}
\hline Class interval & Frequency & Percentage & Cumulative \% \\
\hline$<5$ & 13 & 6.07 & 6.07 \\
$5 \leq 10$ & 68 & 31.78 & 37.85 \\
$11 \leq 15$ & 73 & 34.11 & 71.96 \\
$16 \leq 20$ & 52 & 24.30 & 96.26 \\
$>20$ & 8 & 3.74 & 100 \\
Total & 214 & 100 & \\
\hline
\end{tabular}

Average household size $=12.07$ members

Source: Field Data, 2006

\section{E. Sources of finance for poultry farmers}

Sixty one (61) percent of the small scale poultry farm operators sourced their finance internally from personal savings while $20 \%$ sourced funds from loans obtained from co-operative societies (Table 7). Lack or limited collateral securities, however, made it difficult to obtain bank loans as only 10.28 percent could secure bank loans. Some poultry farmers, sourced finance from a combination of personal savings, bank loans and co-operative societies' loans. Internal sourcing of finance from owners' equity (personal saving) is constrained, as most of the poultry farm operators had a weak financial base. Additional sources of funds are therefore required for the poultry operators to sustainably solidify their financial base with assured increased output level.

Table 7. Sources of finance of the respondents.

\begin{tabular}{lccc}
\hline Source of finance & Frequency & Percentage \% & Cumulative \% \\
\hline Personal saving & 130 & 60.75 & 60.75 \\
Bank loans & 22 & 10.28 & 71.03 \\
Coop. societies & 43 & 20.09 & 91.12 \\
Personal savings/bank loans & 9 & 4.21 & 95.33 \\
Personal savings/coop. socs. & 10 & 4.67 & 100.0 \\
Total & 214 & 100.0 & \\
\hline
\end{tabular}

Source: Field Data, 2006

\section{Determinants of the use of micro- finance}

The Tobit regression model was used to identify the determinants of the use of micro finance by the poultry farm operators. It measured the parameters of the conditional probability of having access to the required level of funds and the marginal changes in explanatory variables on the micro finance status of the poultry units. Respondents were classified into adequately financed $\left(\mathrm{MF}_{1}\right)$ and inadequately financed $\left(\mathrm{MF}_{0}\right)$ group using the fund insecurity line measure $(\mathrm{Z})$ 
as earlier mentioned. To be fund secure, a poultry farm (small scale) required about N 3.5 million per annum, (Ojo, 2003; PANOG, 2005). This takes care of daily upkeep, purchase of vaccines, feeds, new chicks and settlement of overhead costs. Any farm operating below this line was therefore categorized as operating below the fund secure line. The regression parameters and diagnostic statistics were estimated using the maximum likelihood estimation (MLE) technique (Table 8).

Results showed that only five out of the nine listed regressors had significant influence on the fund insecurity status of the poultry farms. The sigma square $\left(\sigma^{2}\right)$ value was 0.5448 , with a $p$-value of less than 0.01 and $\log$ likelihood function of 213.113. Hence, sigma square was statistically significant, thus indicating that the model displays a good fit. The variables that had significant co-efficient are educational status $\left(\mathrm{X}_{2}\right)$, years of poultry keeping $\left(\mathrm{X}_{3}\right)$, household size $\left(\mathrm{X}_{4}\right)$, interest rate on loans $\left(\mathrm{X}_{5}\right)$ and number of poultry birds $\left(\mathrm{X}_{6}\right)$.

It should be noted that a positive sign on a parameter indicated that higher values of the variables tend to reduce the likelihood of fund insecurity. Similarly, a negative value of a co-efficient implied that higher values of the variables would increase the probability of fund insecurity. Specifically, age of the farmer $\left(\mathrm{X}_{1}\right)$, household size $\left(\mathrm{X}_{4}\right)$ and interest rate $\left(\mathrm{X}_{5}\right)$ with negative parameter co-efficients agreed with the a priori expectations. Other parameters like the level of education, experience in poultry keeping, number of poultry birds and total annual expenditure had positive co-efficients which again agreed with the a priori expectations. Only level of education, poultry keeping experience, number of poultry birds and input usage were significant variables at $1 \%$ while household size and interest rate were significant at $5 \%$ level. The probability of fund security was highest for household size (0.8570) and least for level of education (0.0071), implying that increasing poultry farm labours through harnessing of family labour was the most desirable. Intensity of financing was highest for input usage (0.1318) and least for experience (0.0013). This implied that input procurement and usage attracted highest funding. This had a direct bearing on policy formulation as good quality and sufficient feeds were required for good performance of poultry birds. Hence, good quality feed should attract topmost importance on the priority list of the investors in poultry business.

\section{Conclusion}

Insufficient funding of small-scale poultry has limited the spate of development of the industry in south western Nigeria. This has often caused low level of production output in the industry. In this study therefore, the extent of micro-financing in small-scale poultry business was investigated. The sample consisted of 214 small-scale poultry farmers who were selected through multistage sampling technique. For the poultry farmers to be fund secure they needed to improve on their level of education, years of experience in poultry farming, number of poultry birds and total annual expenditure. Interest rates on loans obtained for poultry keeping should be moderate and affordable while the quality and quantities of input facilities such as feeds, drugs and vaccines and water should increase. This is a major challenge to policymakers and operators of credit institutions such as banks and cooperative societies. Finally, as more funds were made available to the small scale poultry farmers at minimal costs, the level of output in industry will improve. 
Emir. J. Food Agric. 2007. 19 (2): 38-47

http://www.cfa.uaeu.ac.ae/research/ejfa.htm

Table 8. Tobit parameter estimates of probability and effect of the marginal changes in the explanatory variables on the fund insecurity status of the poultry outfits.

\begin{tabular}{lcccc}
\hline Variable & Coefficient & Std. Error & $\begin{array}{c}\text { Prob. of fund } \\
\text { security }\end{array}$ & $\begin{array}{c}\text { Intensity of } \\
\text { micro-financing }\end{array}$ \\
\hline Constant & -0.3930 & 0.3212 & 0.0733 & -0.0124 \\
Age $\left(\mathrm{X}_{1}\right)$ & -0.0053 & 0.0114 & 0.0442 & 0.0345 \\
Education $\left(\mathrm{X}_{2}\right)$ & $0.0134^{*}$ & 0.0042 & 0.0071 & 0.0061 \\
Experience $\left(\mathrm{X}_{3}\right)$ & $0.0178^{*}$ & 0.0031 & 0.5134 & 0.0013 \\
Household size $\left(\mathrm{X}_{4}\right)$ & $-0.0844^{* *}$ & 0.0319 & 0.8570 & -0.3149 \\
Interest rate $\left(\mathrm{X}_{5}\right)$ & $-0.3821^{* *}$ & 0.1415 & 0.3204 & 0.0016 \\
No of birds $\left(\mathrm{X}_{6}\right)$ & $0.3218^{*}$ & 0.0164 & 0.1009 & 0.1138 \\
Total annual Expenditure $\left(\mathrm{X}_{7}\right)$ & $0.0189^{*}$ & 0.0035 & 0.4301 & 0.1081 \\
Gender $\left(\mathrm{X}_{8}\right)$ & $0.0199 * * *$ & 0.0112 & 0.06181 & 0.0028 \\
Input usage $\left(\mathrm{X}_{9}\right)$ & $0.0638^{*}$ & 0.0061 & 0.1487 & 0.1318
\end{tabular}

*Significant at $1 \%$;* Significant at $5 \%$;** Significant at $10 \%$

Dependent Variable: Fund security index (FSI)

Sigma Square $\sigma^{2}: 0.5448 ; \quad \mathrm{P}<0.01$

Log likelihood function: -213.113

Source: Computed from survey data, 2006

\section{References}

Adesina, A. A and J. Baidu-Forson. 1995. Farmers' perception and adoption of new agricultural technology: evidence from analysis in Burkina Faso and Guinea,West Africa. The Journal of International Association of Agricultural Economics. 13(1):1-9.

Ahrendsen, B. L., C. B. Dodson, B. L. Dixon and S.R. Koenig. 2005. Research on USDA Farm Credit Programs:Past,Present and Future.Agricultural Finance Review. 65( 2):31-35

Baidu-Forson, J. 1999. Factors influencing adoption of land enhancing technology in the Sahel: Lessons from a case study in Nigeria. The Journal of International Association of Agricultural Economics.20(3):231239.
Ellinger, P. N., V. Hartarska, and C. Wilson. $2005 . \quad$ Structure, Performance, and Risk Management of Financial Institutions. Agricultural Finance Review. 65(2): 42-45

FRN. 2000. Federal Republic of Nigeria: Obasanjo's Economic Direction 19992003 pp.15-18. Dawn functions Nigeria limited, pp.15-18.

Kota, I. 2007. Microfinance: Banking for the poor,'In 'Unleashing the Economic Power of Women'.Finance and Development . pp 44-45.

McDonald, J. F and, R. A. Moffit. 1980. The Uses of Tobit Analysis. Review of Economics and Statistics. 62:318321.

Oboth G. A. T. 2003. Financing poultry production in Nigeria: The role of commercial Banks. The publication of Poultry Association of Nigeria, Ogun state chapter. pp37. 
Ogunfowora, O., B. L. Fetuga, A. A. Ademosun, S. A. Offion, A. Akinola and J. Koopman. 1975. A survey of the Livestock Situation in Nigeria.Federal Livestock Department. pp 204.

Ojo, S. O. 2003. Productivity and technical efficiency of poultry egg production in Nigeria. International Journal of Poultry Science. 2(6):459-464.

Okoli, E. 1991. The State of livestock industry in Nigeria. EK-OVET magazine.Publication of Nigerian Veterinary Medical Association (NVMA), Lagos State Branch. 6(1):30-32.

Oludimu, O. L, A. A. Awojobi and K. A. Akanni. 2004. Analysis of Poultry Insurance and Risk Management in Ogun State, Nigeria. Journal of Agricultural Management and Rural Development (JAMARD). 1:64-84.
Oludimu, O. L. and Y. L. Fabiyi. 1983. The mobilization of credit for Agricultural Development in Anambra State, Nigeria. Savings and Development 4(4):120-122.

Oyenuga, V. A, S. Jakondas, G. Babatunde, J. A. Oluyemi, O. Ogunfowora and B. L. Fetuga.1977. The compound livestock feed industry in Nigeria.Journal of rural economics and development.11(2).

PANOG. 2005. Poultry Association of Nigeria, Ogun State Chapter. Quarterly bulletins.

The Mirocredit Summit Campaign. 2006. State of the Microcredit Summit Campign Report.Finance and Development. pp17-21. 